

\title{
AN EVALUATION OF THE FACTORS INFLUENCING VEGETABLE COMMERCIALIZATION IN KENYA
}

\author{
1* Mbiti Job M'ithibutu \\ School of Agricultural Sciences and Agribusiness Pwani University \\ *Corresponding Author's E-mail: jobithibu@gmail.com \\ ${ }^{2}$ Dr. Elisha Otieno Gogo \\ Lecturer, School of Agricultural Sciences and Agribusiness Pwani University \\ ${ }^{3}$ Dr. Fikirini Lugogo Mangale \\ Lecturer, School of Business Management and Economics Pwani University \\ ${ }^{4}$ Prof. Gregory Baker
}

Professor, Department of Management and Entrepreneurship Santa Clara University 


\begin{abstract}
Purpose: The purpose of the study was to establish factors that influence vegetable commercialization among smallholder farmers of fresh vegetables in Kenya. The present study defined commercialization against farmer characteristics including portion of land committed to vegetable farming, share of household income generated from it, and the producers' perception that the vegetables they consumed at the farm were produced or procured without any substantial cost.
\end{abstract}

Methodology: The researcher adopted a cross-sectional survey design to randomly recruit a sample of crop farmers $(n=118)$ from Kirinyaga and Kiambu counties in Kenya. Data on agrochemical use, crop diversity and scale as well as logistical issues regarding proximity to markets and social status of the crop farmers were collected using a researcher-administered questionnaire in a one-on-one interview. These data were initially entered on MS Excel spread sheets for cleaning and later transferred to Minitab (Ver 12) for statistical analyses. Principal component analysis (PCA) was used to isolate crucial commercialization factors responsible for varying agrochemical use behaviours among crop farmers and later presented in scree plots.

Results/Findings: The study revealed that commercialization of tomatoes and kale was real in different areas of study which was influenced by structural and socio-demographic factors. From the study findings, structural policies to promote horticulture and high value crop production had a positive impact on production of vegetables while wildlife conservation and livestock development resulted to human-wildlife conflicts due to agrochemical abuse. Various sociodemographic factors that influence commercialization of vegetables included: household size, farm size, proportion of land used for vegetable production and household income. It emerged that household size (Eigen value $E V=3.63)$, income $(E V=2.61)$ and farm size $(E V=1.27)$ accounted for $68.4 \%$ of variability in agrochemical abuse. This finding also explains their marginalization from county government extension services and high costs of market access.

Unique contribution to theories, practice and policy: The study finds that vegetable farmers' perception of commercialization leaned more towards increasing production in response to consumer demand and not necessarily to raise household food supplies. Famers dedicated over two thirds $(66.67 \%)$ of their land to vegetable farming to support their livelihood $(97.1 \%, \mathrm{SE}=$ 1.30). Commercialization of vegetable farming was influenced by the level of education $(\mathrm{SE}=3.68)$. The study found out that that access to ICT equipment, particularly mobile phones, were the prime means via which farming techniques and agribusiness practices were learnt or improved ( $\mathrm{V}=0.196$ Pearson, $\mathrm{p}=0.11)$.

Key words: Commercialization, Vegetable, Agrochemicals 
International Journal of Agriculture

ISSN 2520-4629X (Online)

Vol.6, Issue 1, No.1.pp 1 - 19, 2021

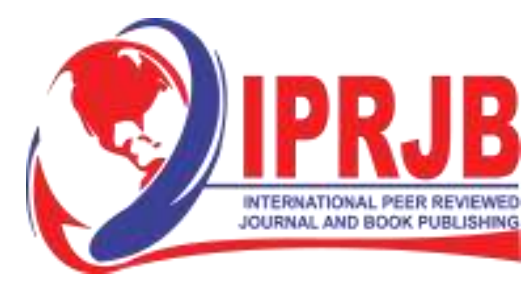

WWW.iprjb.org

\subsection{INTRODUCTION}

Agricultural commercialization refers to the orientation of individual farm enterprises or optimization of to input and output markets coupled with decision making component (von Braun \& Kennedy, 1994; Pingali, 1997) with the aim of increasing productivity and profits. Therefore, smallholder commercialization encompasses going beyond the food self-sufficiency goal by adopting productivity enhancers and offloading the surplus to the market (Kiriathi, Kassim and Kimanya, 2016). In addition, the increased productivity from commercialization results to household income growth which is an indicator of increased purchasing power and improved welfare which contributes to changes in food consumption patterns among producers (Dorsey, 1999; Seale et al., 2003; Moti et al., 2009, Kirimi et al., 2013). Gross domestic product (GDP) growth originating from agriculture has been acknowledged to have higher positive impact (2-4 times) on incomes of extremely poor category compared to growth from other sectors (AGRA, 2014), therefore vital for development of developing economies (Thorbecke, 1970; Diao et al., 2007; Cervantes-Godoy \& Dewbr, 2010). Literature indicates that agricultural commercialization is vital in the structuring and transformative aspects of an economy (von Braun 1995; Pingali \& Rosegrant, 1995; Timmer 1997; Pender \& Alemu, 2007; Moti et al., 2009) especially in the developing ones. Cervantes-Godoy and Dewbr (2010) point out that economic growth especially agricultural related is fueled by among other factors access to input and output market; a basis for agricultural commercialization. Sharma et al. (2015) recognizes that agricultural commercialization is driven by demand and supply forces with the changing food consumption trends as well as production regimes in a locality, economic growth, demographic changes, technology, urbanization and modernization of agricultural food markets.

Commercialization addresses the increasing challenges in deficient soil fertility, pest and disease prevalence on one hand and need to increase agricultural productivity and income returns on the other hand, thus necessitating the use of agrochemicals. Further to this, in effort to meet the specific demand attributes (cosmetic quality) such as color, outlook (spotlessness), size, shape, texture and taste by target consumers, farmers have resulted to use of agrochemicals (Thrupp et al., 1995; Okello \& Swinton, 2010). The use of external inputs is further legitimized by the need to increase production in order to meet the increasing food demand for the surging population and the changing population structure. This trend compliments the 'green revolution' movement which has been advocating for crop varietal development and input use as a basis for agricultural development since 1950s (The Royal Society, 2009). The use of external inputs has been lauded as a basis for embracing science in agricultural commercialization and as a result reaping the ensuing benefits (The Royal Society, 2009).

The world population is expected to expand by about a billion people by 2030 and another 2 billion by 2050 (Bjørndal et al., 2014). This demographic expansion is anticipated to be most pronounced in Africa (Mubila, 2012; Bremner, 2012). Specifically, the Sub-Saharan Africa (SSA) region, currently the poorest in the world, will contribute $46 \%$ of the world's total births by 2050 . Kenya, a developing country, located within the Eastern part of the SSA and whose population was estimated to be 43.35 million in 2013 (World Bank, 2016) is projected to reach 60 million by 2030 and 77 million by 2050 (GoK, 2012). Out of the estimated total population of 
International Journal of Agriculture

ISSN 2520-4629X (Online)

Vol.6, Issue 1, No.1. pp 1 - 19, 2021

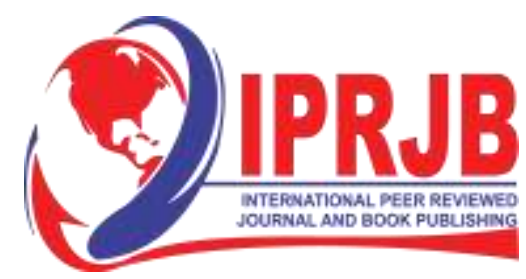

www.iprjb.org

40.91 million in 2010 for Kenya, approximately 20.1 million people (49\%) were categorized as poor (KIPPRA, 2013) where almost $80 \%$ of the overall population depend on agriculture for its livelihood. Whether it is from a global or national perspective, these population changes present a challenge and an opportunity in provision of adequate, nutritious and safe food. Putting up the required structures to ensure food demand is met may be a challenge but availing these foods present an opportunity for increased returns in food supply chains.

There is a general agreement that the increasing population is an indicator of growing food demand (Regmi et al., 2001; Hui \& Wen, 2007; Bjørndal et al., 2014). As a result, an increase in food production by at least 50\% will be required globally by 2050 (The Royal Society, 2009). The anticipated changes in the structure of the population especially age, sex, income, level of education and urban/rural orientation across the globe will complicate the future consumption patterns and food needs (Bjørndal et al., 2014

In Kenya, food production falls way below consumption and will need to increase by $75 \%$ from 2015 levels in order to match consumption in by 2030 (Welborn, 2018). Kenya's agricultural sector, the eighth biggest in Africa by volume, has attempted to keep pace with consumption since the late 1990s. Nonetheless, the contrast between sustenance free market activities stayed under two metric tons until 2009 (ISS, 2018). Furthermore, as indicated by the International Futures (IFs) forecasting framework housed at the Frederick S Pardee Center for International Futures at the University of Denver, the gap between consumption and production is anticipated to broaden going ahead (ISS, 2018). IFs forecasts that consumption in Kenya will surpass production by about 20 million metric tons by 2040. This implies imports would need to meet $25 \%$ of rural interest.

Findings by Food and Agricultural Organization and World Water Council gauge that by 2050, the world will require $60 \%$ more food to sustain its growing population (Valin et al., 2014). In Kenya, the force of the issue is all reflected in the government's choice to incorporate food security in its "Big Four Agenda"; Enhancing Manufacturing, Food Security and Nutrition, Universal Health Coverage and Affordable Housing which spells out the government's need zones priorities (GoK, 2019). Here, farming backing up to $75 \%$ of the population and produces all the nation's sustenance necessities.

Commercialization of agricultural produce and especially vegetables through improved participation in output markets has been supported as one of the best approach to address low agricultural output that has led to high levels food insecurity in developing countries such as Kenya (Ngenoh et al., 2019; Abdullah et al., 2019; Olwande \& Mathenge, 2011; Wickramasinghe, 2015). In addition, the market liberalization policies that were widely promoted in Kenya in the 1990s under structural adjustment programs (SAPs) were generally meant to encourage agricultural commercialization. Covertly, however, these liberalization policies also aimed at opening up new economic hotspots. This outcome has not been impressive.

As of today, many rural producers continue to practice the traditional survival agriculture and consequently unable to realize full potential from commercialization prospects presented by the liberalized markets (Pinder \& Wood, 2003). Equally, for many years, local agricultural markets 
International Journal of Agriculture

ISSN 2520-4629X (Online)

Vol.6, Issue 1, No.1.pp 1 - 19, 2021

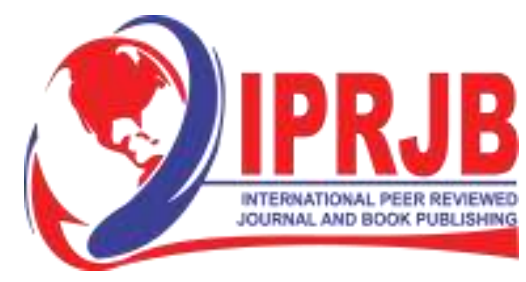

www.iprjb.org

in Kenya were profoundly protected against cheap imports and a time government has been supporting producer output prices through parastatals (FAO, 2015).

The market liberalization policies are aimed at protecting the welfare of the producer and the country at large. Conversely, owing to the international food crisis of 2006 and 2008 and subsequent post-election violence, food prices went up sharply with poor households being worst hit. Although the food prices have dropped since 2009, they still remain higher compared to the period before the crisis and predictions point to that there is a likelihood that they will remain so for the next 20 years (IFAD, 2011). Up to now, considerable amount of the production are in response to these higher food prices (IFAD, 2011).

\subsection{Statement of the Problem}

Outspoken authors on vegetable commercialization in Kenya argue that it could improve the livelihoods of corresponding farmers and improve the economy of the country by first responding to household demands for food. This view resonates well with local needs to combat poverty and hunger in the region and has therefore become increasingly popular among policymakers and civil society agencies. Theoretically, the view also fits well within the utility maximization theory (UMT).

However, authors also admit that this conclusion was reached in the absence of data and a poor understanding of the factors that compel farmers to commercialize vegetable farming. Strangely, researchers continue to interpret these producer patterns against structural and demographic characteristics such as level of education or proximity to markets. The risk has been the creation of a smoke-screen around real concerns of farmers such as access to capital and extension services, wildlife depredation or even more controversial, the privatization of seed and agrochemicals by big multinationals.

This study casts the farmers' choice to adopt and practice vegetable commercialization within the utility maximization theory (UMT) and finds significant faults in its principal aim of increasing production and income. This is portrayed as short-sighted and capable of endangering the farmer's long-term household food supplies. The proposed logic argues that commercialization compromises agrochemical ethics and could thus undermine the safety and acceptability of farmers' produce in the market. Finally, the researcher disputes the relationship between the farmer's livelihood and their ability to address the food security of marginalized groups in the society.

Unlike the export markets, domestic markets have not been keen to ascertain the safety of local foods, particularly, fresh vegetable targeting domestic consumers (Gitonga et al., 2010). As a result, levels of pesticide residues capable of harming human health have been detected in fresh vegetables such as tomatoes destined for local markets (Kiriathi, Kassim and Kimanya, 2016). There have also been allegations to suggest that fresh produce that fails to satisfy export market demands is diverted back to the domestic food supply chains. In addition, the country's consumer welfare watchdog has not been outspoken in order to initiate debate and policy action in relation to the booming agricultural commercialization especially vegetables as far as agribusiness ethics compliance by fresh food producers (Muriithi \& Matz, 2014). 


\subsection{Research Objective.}

i. The study sought to determine the factors influencing vegetable commercialization in Kenya

\subsection{LITERATURE REVIEW}

\subsection{Theoretical Framework}

\subsubsection{Utility Maximization Theory}

Several theories have been advanced to describe consumer behavior towards aspects of vegetable commercialization, agribusiness ethics and chemical safety of foods. However, their limitation is their inability to offer an integrated explanation that combines commercialization factors from the producer and consumer as well as, ethics and safety. For this reason, the researcher adopts the Utility Maximization Theory (UMT).

According to the theory, consumers are increasingly choosing among alternative goods within their limited incomes (Chernov \& Hamilton, 2009) with the aim of spending each last cent on products that yield the highest marginal utility (or satisfaction) possible (Stigler, 1950). Utility theory bases its beliefs upon individuals' preferences. It explains behavior of individuals based on the premise people can consistently rank order their choices depending upon their preferences. Each individual will show different preferences, which appear to be hard-wired within each individual.

Studies on vegetable commercialization attribute its advent and popularity on government and donor efforts to increase production and offer a means to alleviate poverty among small farmholders (Gebru et al., 2019) in rural areas. In a sense, therefore, commercialization could be seen as a push-pull affair aided by the entire market with the aim of maximizing product penetration (quantity and quality).

Given that poverty is multidimensional, its alleviation through commercialization could consider much more than direct costs of production including other livelihood needs such as healthcare. The socioeconomic burden of disease due to agrochemicals is already incredible enough to erode the benefits of commercialization (Dewbr, 2010). Globally, for instance, more than 350,000 people globally suffer acute poisoning due to herbicide and insecticide (Ko et al., 2018) and this costs Kenyan farmers about $47 \%$ of their household income (Macharia, 2015). Interestingly and despite the intensive use of agrochemicals, commercialization in the horticulture industry has been shown to increase household income and asset value for Kenyan farmers (Muriithi and Matz, 2014) and contribute to poverty alleviation. This underscores the significance of strict safety regulations particularly for export market and urban supermarkets. Otherwise, the burden of agrochemicals undermines the industry's contribution to alleviate poverty and in turn hinders commercialization. In the context of UMT, agrochemical safety presents an objective rationale for vegetable producers to maximize satisfaction for consumers. 
International Journal of Agriculture

ISSN 2520-4629X (Online)

Vol.6, Issue 1, No.1.pp 1 - 19, 2021

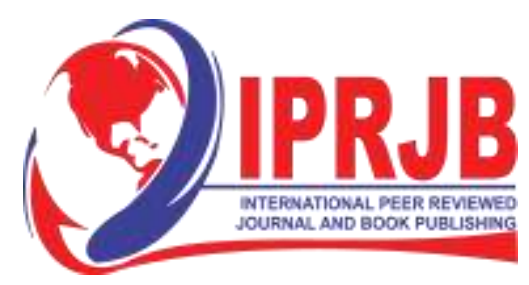

WWW.iprjb.org

\subsection{Research Gaps: Critical Review of Literature}

Empirical literature to appreciate the inadequate production market participation in post foodprice crisis era is still very few. Most of them were based on output market participation of one or just a few selected crops especially cereals yet smallholder commercialization involves largely vegetables including the indigenous vegetables (Jaleta, 2009). In terms of policies in Kenya, The National Food Safety Policy and the National Food Nutrition and Security Policy ignore consumer sensitization and involvement (Oloo, 2010). An empowered consumer will raise the red flag in the event of suspected contamination. Tough policies and regulations should scrutinize and authorize different actors in the value chain and provide the consumer with the vital information for proper decision making.

Literature shows substantial research on food demand (Regmi et al., 2001), agricultural commercialization across the globe (von Braun \& Kennedy, 1995; Mahaliyanaarachchi \& Bandara, 2006), in Thailand (Tipraqsa \& Schreinemachers, 2009), SSA (Nindi, 1993; Govereh et al., 1999; Berhanu et al., 2006; Pender \& Alemu, 2007; Moti et al., 2009; Zhou et al., 2013; Tirkaso, 2013), in Kenya (Chiputwa \& Qaim, 2014; Muriithi \& Matz, 2014; Woolverton \& Neven, 2014). Available literature shows that there is scarcity of knowledge on vital connection of components in the agri-food supply chain such as consumer food demand, agricultural commercialization, and agribusiness ethics in commercialization and food safety. Researchers have largely failed to establish the link among these vital components across food supply chains. This study sought to build on the existing literature to fill in the research gaps by establishing the link among these components in the regenerative vegetable supply chain while focusing on the effect of vegetable commercialization on agribusiness regulatory compliance and food safety, an area that has been minimally researched on.

\subsection{RESEARCH METHODOLOGY}

\subsection{Research Design}

The study adopted a mixed methods approach. The descriptive design describes the state of affairs as it exists at present (Kothari, 2004).

\subsection{Target Population}

The target population consisted of all households in Nairobi, Kiambu and Kirinyaga counties. The accessible population comprised of 1,405,092 household units and is summarized in Table below:

\begin{tabular}{|l|l|}
\hline County & Population \\
\hline Nairobi (Westlands) & 860,464 \\
\hline Kirinyaga & 134,719 \\
\hline Kiambu & 409,909 \\
\hline Totals & $\mathbf{1 , 4 0 5 , 0 9 2}$ \\
\hline
\end{tabular}

Source: (KNBS, 2013) 


\subsection{Sample Size}

A total of 384 households in the three counties were interviewed. The following formula was adopted in calculating the sample size (Delice, 2002).

$$
n=\frac{N Z^{2} \times 0.25}{d^{2} \times(N-1)+\left(Z^{2}+0.25\right)}
$$

Where, $\mathrm{n}=$ sample size

$\mathrm{N}=$ Target population

$\mathrm{d}=$ precision level normally expressed in terms of 0.05

$\mathrm{Z}=$ number of Standard Deviation (SD) units of the sampling distribution correct to desired confidence level

$\mathrm{N}=1,405,092$

$\mathrm{d}=0.05$

$\mathrm{Z}=1.96$

$1405092 \times 1.96^{2} \times 0.25$

$$
0.05^{2} \times(1405092-1)+\left(1.96^{2}+0.25\right)
$$

$\mathrm{n}=384$ households units

The sample size for each county was then allocated in proportion to the population of each county as shown below:

Kiambu County (Producers)

$$
\frac{409909}{1405092} * 384=112
$$

Kirinyaga County (Producers)

$$
\frac{134,719}{1405092} * 384=36
$$

Nairobi County (Consumers)

$$
\frac{860,464}{1405092} * 384=235
$$

\subsubsection{Sampling Procedure and Technique.}

The study used three main sampling techniques; judgment sampling stratified sampling and simple random sampling which are both non-probabilistic and probabilistic in nature. The study applied judgment sampling to select Kirinyaga, Kiambu and Nairobi Counties. Kothari and Gaarg (2019) have already explained how judgment sampling could be used when the study has to be biased in selection towards preferred criteria. The Economic Survey 2019 lists Kirinyaga County among the leading tomato producing counties in Kenya while Kiambu is a major source of African Kales (Sukuma wiki). Nairobi County is a main market for produce. 


\subsection{Data Collection Tools}

Self-administered questionnaires and personal interview schedules were used during data collection, applying both open-ended and closed-ended questions. Kothari and Gaarg (2019) explained how closed-ended questions helped in standardizing responses while open-ended questions described the researchers' conclusions.

\subsection{Data Analysis and Presentation}

The analysis sought to test factors that predict the adoption (presence or absence) of vegetable commercialization in the study area. The following binary logit model was adopted from Jong et al (2019) to explain the influence of these factors on commercialization:

$$
\pi i j(\mathrm{xi})=\frac{\exp \left(\alpha j+\beta^{\prime} j x i\right)}{1+\sum_{h=1}^{J-1} \exp \left(\alpha h+\beta^{\prime} h x i\right)}
$$

Where: $y_{\mathrm{ij}}$ denote the presence $\left(y_{\mathrm{ij}}=1\right)$ or absence $\left(y_{i j}=0\right)$ of multinomial outcomes $j, j=1, \ldots$ ,J, for observation $i, i=1, \ldots, N ;\left(\beta_{j 1}, \ldots, \beta_{j R}\right)$ ' denotes the coefficients for the $j^{\text {th }}$ linear predictor, except its intercept $\alpha j$. For the reference outcome, $\left.\pi i j(x i)=1 / 1+\sum_{h=1}^{J-1} \exp \left(\alpha h+\beta^{\prime} h x i\right)\right)$.

The table below outlines some of the consumer and producer factors that have been shown in literature to influence vegetable commercialization. The multinomial regression model would help sift through to identify factors that were significant (have p-values below 0.05) and relevant (have a coefficient of determination above 0.1 ) in vegetable commercialization

\subsection{RESULT AND DISCUSSION}

\subsection{Is vegetable commercialization real?}

The initial challenge for the study was to prove a case for commercialization. This was achieved in the following four ways, firstly, by evaluating the sources from which consumers purchased their vegetables in which case commercialization was implied if a majority of consumers purchased rather than produced the vegetables they needed. Secondly, commercialization was implied if a farmer committed a significant portion of land to vegetable farming or secured a sizeable share of household income from it. Thirdly, there was commercialization if the farmer drew a substantial amount of household income from vegetable income. Fourth and lastly, commercialization was implied if the producers perceived that the vegetables they consumed at the farm were produced or procured without any substantial cost. This was used as a benchmark for drawing comparisons with the other forms of commercialization.

\subsection{What factors influence vegetable commercialization in the study area?}

\section{Ready market or demand}

Under the first criterion, the study found that about $98.72 \%$ of the consumers sampled reported consuming both kales and tomatoes regularly. This ranged from once every day for $36.6 \%$ of respondents, to about twice or thrice every day for $30.64 \%$ of respondents, respectively. Only 
International Journal of Agriculture

ISSN 2520-4629X (Online)

Vol.6, Issue 1, No.1.pp 1 - 19, 2021

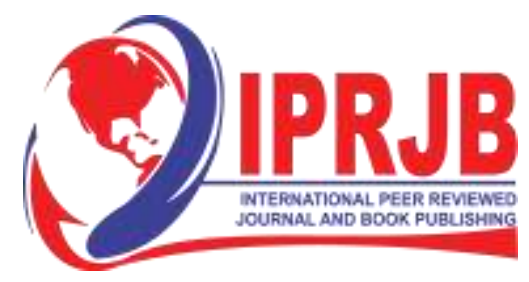

www.iprjb.org

$1.28 \%$ of respondents consumed kales alone but none consumed tomatoes alone. Very few $(0.43 \%)$ reported not consuming vegetables in a given week.

All respondents acknowledged sourcing their vegetables from the market out of which a majority (76.6\%) relied on nearby traders, supermarkets $(9.36 \%)$, county markets $(0.43 \%)$ or a combination of all sources (13.62\%). Demand was, therefore, deemed a crucial factor influencing vegetable commercialization in the study area and about half (49.36\%) of respondent consumers felt that this demand was growing. However, $42.55 \%$ felt that it remained normal and even fewer $(8.09 \%)$ felt that it was declining.

Access to land

A majority of farmers were seen to utilize a substantial share of their land with the aim of maximizing income from vegetable farming. For instance, about $50 \%$ of crop farmers were utilizing between $66.67 \%-100 \%$ of the total land for vegetable farming. Similarly, the data returned very high mean farm utilization for vegetable farming of about $81.86 \%$ ( $\mathrm{SE}=2.88$ ).

Easy source of livelihood or household income

A substantial share of farmers depended on the income they drew from vegetable farming for livelihood needs. At least $97.1 \%$ of farmers reported that revenues from vegetable farming contributed $100 \%$ of their household income. The mean contribution of vegetable revenues to household income was $98.19 \%$ ( $\mathrm{SE}=1.30$ ) and to only $1.45 \%$ and $2.9 \%$ of the farmers interviewed did vegetable revenue contribute less than $25 \%$ and $50 \%$ of household income, respectively. Female farmers were slightly more dependent (mean household contribution $=$ $98.53 \%, \mathrm{SE}=1.47$ ) on vegetable revenues for livelihood than their male counterparts (mean household income $=97.86 \%, \mathrm{SE}=2.14)$. Likewise, widows and unmarried farmers were more dependent on vegetable income (mean household contribution $=100 \%, \mathrm{SE}=0.00$ ) compared to their married counterparts (mean household contribution $=97.02 \%, \mathrm{SE}=2.12$ ).

On average, farmers in Kiambu County reported a slightly higher dependency on vegetable revenues for livelihood at about 99.303 ( $\mathrm{SE}=0.492 \mathrm{Min}=60 \% \mathrm{Max}=100 \%$ ) compared to their counterparts in Kirinyaga at about $96.71 \%$ ( $\mathrm{SE}=2.34 \mathrm{Min}=25 \% \mathrm{Max}=100 \%$ ). This could hint to some persistent traces of subsistence farming. For instance, about $98.198 \%$ of Kiambu farmers reported $100 \%$ dependency compared to $94.737 \%$ in Kirinyaga. Dependency was also influenced by the choice of vegetables grown. Farmers who grew kales were more likely $(99.029 \%)$ to wholly depend on its revenues for household income, and livelihood as well, compared to those who grew both kales and tomato $(93.103 \%)$ or those who only grew tomato $(94.118 \%)$.

Level of education caused unexpected variation in the farmers' dependence on vegetable income. For instance, persons without any formal education, those with primary education and strangely those with college or university education reported $100 \%$ dependence on vegetable income $(\mathrm{SE}=0.00)$. It is farmers with secondary education that reported slightly less dependence of $94.79 \%(\mathrm{SE}=3.68)$.

Access to information and information technology 
International Journal of Agriculture

ISSN 2520-4629X (Online)

Vol.6, Issue 1, No.1.pp 1 - 19, 2021

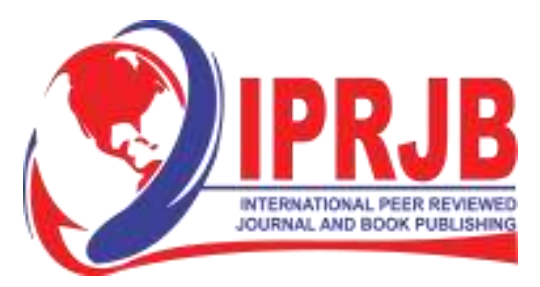

www.iprjb.org

Factors relating to information access appeared to vary dependence on vegetable incomes. These included information technology in which case farmers relying on computers and mobile phones to access farming information appeared most dependent (mean vegetable contribution $=100 \%$, $\mathrm{SE}=0.00)$ compared to those relying on mobile phones only $(97.66 \%, \mathrm{SE}=2.34)$ or those with none $(98.48 \%, \mathrm{SE}=1.52)$. Nevertheless, ownership of or access to these ICT equipment could infer other underlying factors such as access to capital and the caliber of agribusiness practiced more than the influence of information alone.

\section{Household demands for vegetables}

To test whether farmers perceived their access of vegetables as being a substantial cost to livelihood, the researcher conducted a correlation test between household income and percentage of land utilized for vegetable farming. This was done against the assumption that farmers utilizing less land would do so because alternative sources of income enabled them to procure vegetables without any pressure on household income. The tests returned a correlation coefficient $(\mathrm{R})$ of 0.196 (Pearson, $p=0.11$ ) suggesting that a farmer's acquisition of vegetables was not hinged on household income and vegetable intensification.

\section{Gross influence of factors}

For a more rounded evaluation of factors influencing commercialization, the researcher employed Principal Component Analysis (PCA) targeting both household and farming characteristics outlined above. The characteristics were household size (HH-Size), household income (HH-Income), farm size, size of vegetable land in raw acres (VegLand) or as a percentage of total land (VegLand\%), a farmer's experience (Experience), capital requirements per acre (Capital Req), number of agrochemicals used in a farming season (ACNo) and charges to market facilities. The results are given in the Eigen analysis below.

Table 1: Eigen analysis of factors influencing vegetable commercialization

\begin{tabular}{|l|l|l|l|}
\hline Variable & Eigen Value & Proportion & Cumulative \\
\hline HH-Size & 3.2291 & 0.294 & 0.294 \\
\hline HH Income & 1.9164 & 0.174 & 0.468 \\
\hline Farm size & 1.1812 & 0.107 & 0.575 \\
\hline Veg Land & 1.1442 & 0.104 & 0.679 \\
\hline VegLand\% & 0.9487 & 0.086 & 0.765 \\
\hline Experience & 0.8617 & 0.078 & 0.844 \\
\hline Monthly income & 0.7266 & 0.066 & 0.910 \\
\hline VegShare & 0.5845 & 0.053 & 0.963 \\
\hline Capital Req & 0.3778 & 0.034 & 0.997 \\
\hline ACNo access & 0.0292 & 0.003 & 1.000 \\
\hline $\begin{array}{l}\text { Charges to } \\
\text { market facilities }\end{array}$ & 0.0007 & 0.000 & 1.000 \\
\hline
\end{tabular}

As indicated on the table 1 above, only four factors achieved the cut-off Eigen value of 1.00 (Oshlyansky, Cairns \& Thimbleby, 2007) and above, namely HH Size, HH-Income, Farm size 
and share of vegetable land. However, none of these factors achieved the cut-off loading factor of at least 0.30 to be considered statistically significant (Ibid).

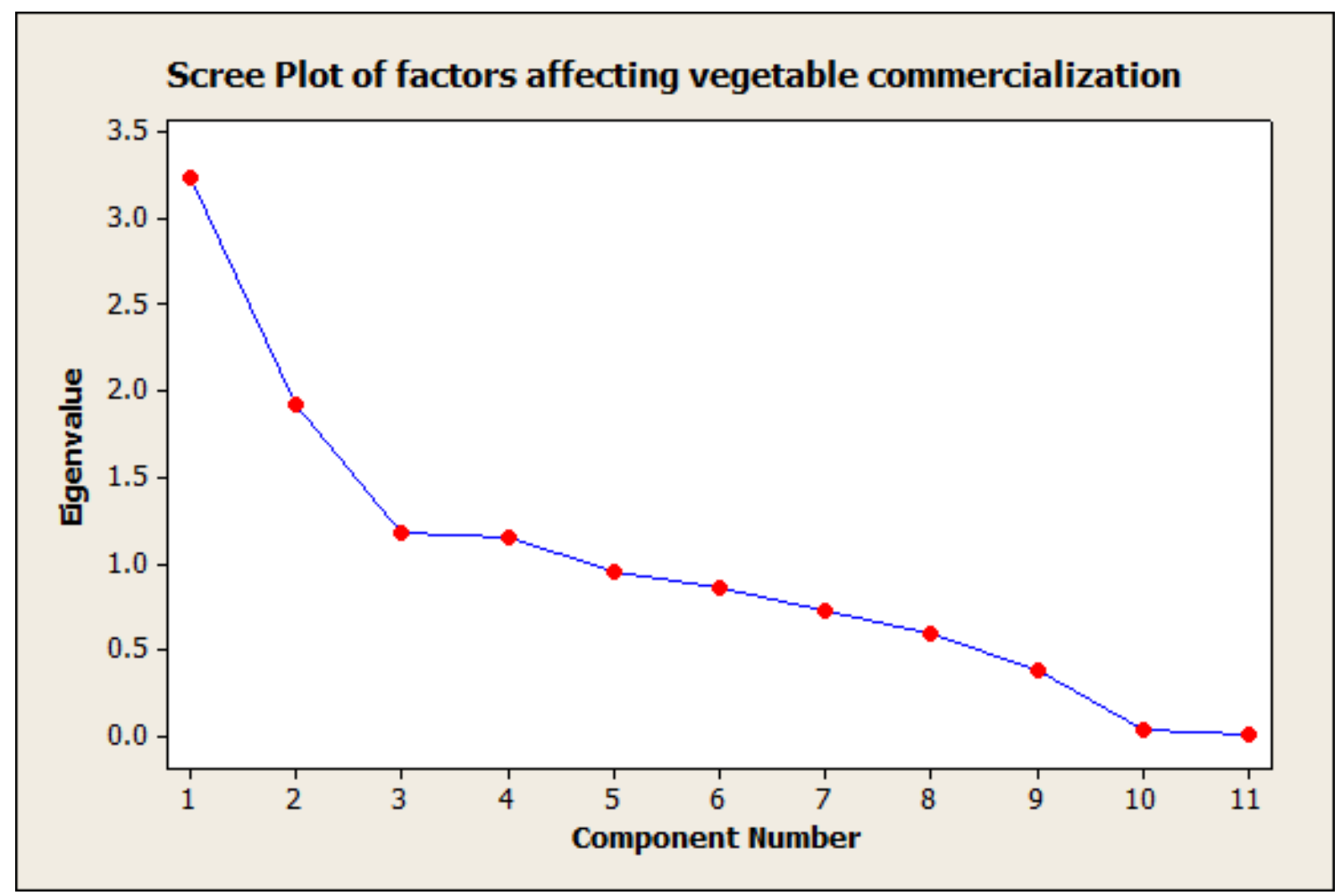

Figure 1: A scree plot of factors influencing vegetable commercialization

\subsection{SUMMARY, CONCLUSIONS AND RECOMMENDATIONS}

\subsection{Summary of the study findings}

The study revealed a great deal of commercialization for tomatoes and kales in the study areas aided by both structural and demographic factors. Inasmuch as structural policies to promote horticulture and high-value crop production in poverty alleviation and food security, some programs hindered this in key tomato and kale production zones for wildlife conservation and livestock development resulting in human-wildlife conflicts and alienation from extension services and a sharp rise in agrochemical abuse. Household and demographic characteristics particularly household size, farm size, proportion of vegetable land as a percentage of total land and share of household income derived from vegetable farming.

The study revealed that over four fifths $(98.72 \%)$ of the buyers were consuming both kales and tomatoes regularly with over three fifths $(67.24 \%)$ of the buyers consuming twice or thrice every day. Majority $(76.6 \%)$ of the respondents sourced their vegetables either from the nearby traders, supermarkets and county markets and while other (23.4\%) visited a combination of all sources. The study found out that demand was crucial factor influencing vegetable commercialization in 
International Journal of Agriculture

ISSN 2520-4629X (Online)

Vol.6, Issue 1, No.1.pp 1 - 19, 2021

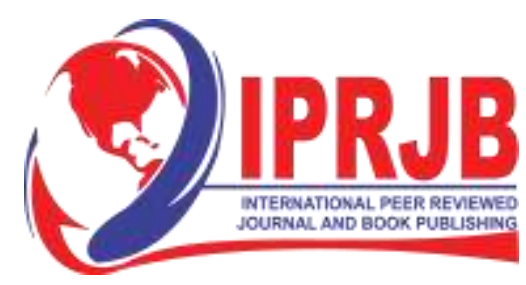

wWw.iprjb.org

the study area, which was rising over time. Majority of farmers were seen to utilize a substantial share of their land with the aim of maximizing income from vegetable farming. About half of the crop farmers were making use over three quarters $(66.67 \%$ - 100\%) of their land for vegetable farming $(\mathrm{SE}=2.88)$. Vegetable farming was viewed as a source of livelihood as well as income $(97.1 \%)$ for the framers that had increased due to increased demand of vegetal in varied areas $(\mathrm{SE}=1.30)$.

Women farmers were slightly more dependent (mean household contribution $=98.53 \%$, $\mathrm{SE}=1.47$ ) on vegetable revenues for livelihood than their male counterparts (mean household income $=97.86 \%, \mathrm{SE}=2.14)$. More importantly, Kiambu County farmers $(99.30 \%)$ depended more on vegetable farming $(\mathrm{SE}=0.492 \mathrm{Min}=60 \% \mathrm{Max}=100 \%)$ in relation to Kirinyaga county farmer ( $\mathrm{SE}=2.34 \mathrm{Min}=25 \% \mathrm{Max}=100 \%$ ) which was influenced by the type of vegetable grown and its marketability. Level of education was a determinant factor on the dependence on vegetable income for people with college and university education depended more on the vegetable farming income which was impacted by their understanding of benefits of agriculture compared to those with secondary education and below who lowery dependent on vegetable farming $(\mathrm{SE}=3.68)$.

Majorly farmers relied on computers and mobile phones to access farming information on farming techniques and varied pest control mechanism. Therefore, the access to these ICT equipment could ease the access to capital and the competence of agribusiness practiced more than the influence of information alone. Farmer's acquisition of vegetables was not significant influencer of household income and vegetable intensification $(\mathrm{V}=0.196$ Pearson, $\mathrm{p}=0.11)$. Eigen analysis showed that HH Size, HH-Income, Farm size and share of vegetable land influenced vegetable commercialization $(3.2291,1.9164,1.1812$ and 1.1442$)$ respectively.

\subsection{Conclusion of the study}

There was high (98.72) consumption of tomatoes and kale which were obtained from the nearby traders, supermarkets and county markets. The study concluded that demand was determinant of vegetable commercialization in the study are over 3 years. More production was crucial to meet the demand of customers. Famers used over three quarters $(66.67 \%)$ of their land for vegetable farming providing for their livelihood $(97.1 \%, \mathrm{SE}=1.30)$. the study concludes that commercialization of vegetable was influenced by demand and household land used for vegetable production.

Commercialization of vegetable farming was influenced by the level of education SE=3.68). The varied farming techniques were learned through mobile phones and computers. The study concludes that the access to ICT equipment improved the competence of agribusiness practices $(\mathrm{V}=0.196$ Pearson, $\mathrm{p}=0.11)$.

\subsection{Recommendation}

The paper attempted to understand factors influencing commercialization of vegetable farming in Kenya, despite the contributions to the existing literature and theory more work needs to be done to provide more knowledge on the commercialization of vegetable farming. In order to provide 
more insights on the subject the study gives various recommendations. The study was limited to three counties. There is therefore need for a similar study to be conducted in the other 43 counties to provide a comparison and variation of factors influencing commercialization of vegetable farming in Kenya. The paper calls for a multi-stakeholder approach to the challenge facing commercialization of vegetables by focusing on public awareness campaigns on consumption of tomatoes and kales utilizing social media and involving civil society groups, public health and environmental regulators.

\subsubsection{Recommendations for Policy}

The study findings portrayed a weakness in the adherence and compliance to agribusiness practices. To enhance adherence and compliance there is a need to enact a policy that will ensure the implementation and adherence of the agribusiness to facilitate practice.

\subsubsection{Recommendations for Practice}

There is need to have regular visits to the agro vets by the government officers to verify the authenticity and credibility of the pesticides sold to the farmers

The government needs to provide incentive for provision of sustainable pest control solutions to the famers including bio control as well as bio-pesticides.

\subsubsection{Recommendations for Further Research}

The study attempted to understand commercialization of vegetable farming on agribusiness ethics compliance and food safety. Despite the contributions to the existing literature, more work need to be done to provide more knowledge on the commercialization of vegetable farming. In order to provide more insights on the subject the study gives various recommendations.

Second, further research needs to be done to understand the perception of community members on the application of agrichemical in the farming of vegetables in the three counties and elsewhere in the country. This would aid in understanding issues awareness and knowledge of side effects of agrichemical on human health and willingness to pay for organically produced vegetables as well as sustainable farming.

Lastly, further research needs to be conducted to understand the involvement of farmers in the formulation of policies and agribusiness practices rules in order to gain knowledge on the level of acceptance of these polices among farmers in Kenya. 
International Journal of Agriculture

ISSN 2520-4629X (Online)

Vol.6, Issue 1, No.1. pp 1 - 19, 2021

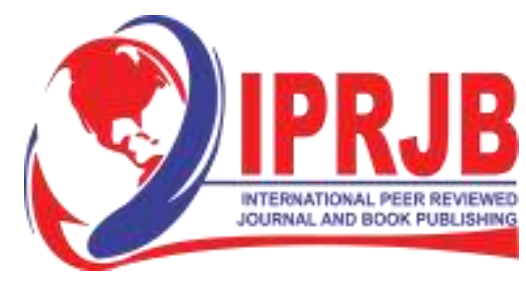

WWW.iprjb.org

\section{REFERENCES}

AGRA. (2014). Africa Agriculture Status Report 2014: Climate Change and Smallholder Agriculture in Sub-Saharan Africa (p. 2018). Nairobi, Kenya. Retrieved from https://reliefweb.int/sites/reliefweb.int/files/resources/agra-africa-agriculture-statusreport-2014.pdf

Agudo, A., Cabrera, L., Amiano, P., Ardanaz, E., Barricarte, A., Berenguer, T., ... Larranaga, N. (2007). Fruit and vegetable intakes, dietary antioxidant nutrients, and total mortality in Spanish adults: Findings from the Spanish cohort of the European Prospective Investigation into Cancer and Nutrition (EPIC-Spain). The American Journal of Clinical Nutrition, 85(6), 1634-1642.

Bazeley, P. (2017). Integrating analyses in mixed methods research. Sage.

Bjørndal, T., Fernandez-Polanco, J., Lappo, A., \& Lem, A. (2014). Consumer trends and preferences in the demand for food. Centre for Applied Research at NHH, 1-31.

Bremner, J. (2012). Population and food security: Africa's challenge. Population Reference Bureau Policy Brief. Retrieved from http://www.prb.org/pdf12/population-food-securityafrica.pdf

Cervantes-Godoy, D and Dewbr, J. (2010). Economic Importance of Agriculture for Poverty Reduction. OECD Food, Agriculture and Fisheries Working Papers, No. 23, OECD Publishing.

COFEK. (2017). About Us. Retrieved from Consumers Federation of Kenya website: http://www.cofek.co.ke/index.php/who-we-are/about-us

D’Alessandro, S. P., Caballero, J., Lichte, J., \& Simpkin, S. (2015). Agricultural Sector Risk Assessment (Report Number 97887; p. 138). Retrieved from Feed the Future, USAID, MFAN, FDEC, World Bank website: Retrieved from http://documents.worldbank.org/curated/en/294711467992513646/pdf/97887-REVISEDWP-P148139-PUBLIC-Box393257B-Kenya-Agricultural-Sector-Risk-Assessment.pdf

Diao, X., Hazell, P., Resnick, D and Thurlow, J. (2007). The Role of Agriculture in Development: Implications for Sub-Saharan Africa. International Food Policy Research Institute; Washington D.C, USA.

Dorsey, B. (1999). Agricultural intensification, diversification and commercial production among smallholder coffee growers in Central Kenya. Economic Geography 75(2):178195.

FAO. (2015). Analysis of price incentives for maize in Kenya for the time period 2005-2013 (p. 44). Retrieved from Food and Agricultural Organisation website: http://www.fao.org/fileadmin/templates/mafap/documents/technical_notes/KENYA/2005 -2013/Kenya_TN_Maize_web_review.pdf

Gitonga, K. J., Gathambiri, C., Kamau, M., Njuguna, K., Muchui, M., Gatambia, E., \& Kiiru, S. (2010). Enhancing small scale farmers' income in mango production through agro- 
International Journal of Agriculture

ISSN 2520-4629X (Online)

Vol.6, Issue 1, No.1. pp 1 - 19, 2021

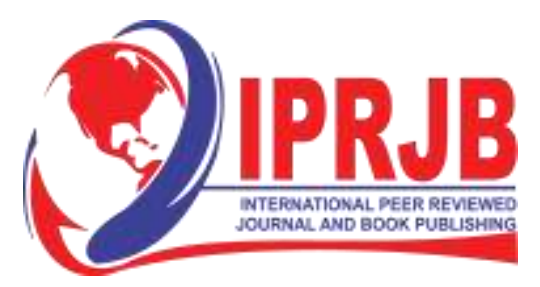

Www.iprjb.org

processing and improved access to markets. Transforming Agriculture for Improved Livelihoods through Agricultural Product Value Chains. Proceedings of the 12th KARI Biennial Scientific Conference, Kenya Agricultural Research Institute, Nairobi, Kenya, 1336-1342.

Horna, D., Smale, M., Al-Hassan, R., Falck-Zepeda, J., \& Timpo, S. (2008). Insecticide Use on Vegetables in Ghana: Would GM Seed Benefit Farmers?

Jaffee, S. (2003). From challenge to opportunity: Transforming Kenya's fresh vegetable trade in the context of emerging food safety and other standards in Europe (No. 31010; pp. 1-76). Retrieved from The World Bank website: http://documents.worldbank.org/curated/en/598771468753012002/From-challenge-toopportunity-transforming-Kenyas-fresh-vegetable-trade-in-the-context-of-emergingfood-safety-and-other-standards-in-Europe

Jallow, M. F. A., Awadh, D. G., Albaho, M. S., Devi, V. Y., \& Thomas, B. M. (2017). Pesticide Knowledge and Safety Practices among Farm Workers in Kuwait: Results of a Survey. International Journal of Environmental Research and Public Health, 14(4). https://doi.org/10.3390/ijerph14040340

Kenmore, P. E., Stannard, C., \& Thompson, P. B. (2004). The ethics of sustainable agricultural intensification (Vol. 4). Food \& Agriculture Org.

Kirimi, L., Gitau, R. \& Olunga, M. (2013). Household food security and commercialization among smallholder farmers in Kenya. A paper prepared for the $4^{\text {th }}$ International Conference of the African Association of Agricultural Economists

Kothari, C. R. (2004). Research methodology: Methods and techniques. New Age International.

Kuranchie-Mensah, H., Yeboah, P., Nyarko, E., \& Golow, A. (2013). Studies on Organochlorine Pesticide Residue in Fishes from the Densu River Basin, Ghana. Bulletin of Environmental Contamination and Toxicology, 90. https://doi.org/10.1007/s00128-012$\underline{0931-1}$

Luijk, R., Schalk, S., \& Muilerman, H. (2000). Have We Lost Our Minds? Neurotoxin Residues Harmful to the Developing Brains of Our Children. Consumentenbond Ans Sticting Natuur En Milieu. The Netherlands.

Mabe, F. N., Talabi, K., \& Danso-Abbeam, G. (2017). Awareness of health implications of agrochemical use: Effects on maize production in Ejura-Sekyedumase municipality, Ghana. Advances in Agriculture, 2017, 1-11.

McDonald, B.(2010). Food Security: Addressing Challenges from Malnutrition, Food Safety and Environmental Change. Retrieved on $04^{\text {th }}$ April 2015 from http://www.psu.edu/dept/liberalarts/sites/rockethics/documents/mcdonald/McDonald\%20 Food\%20Security\%20Washington\%20May\%202011.pdf

Moti, J., Berhanu, G. and Hoekstra, D. 2009. Smallholder commercialization: Processes, determinants and impact. [Discussion Paper No. 18]. Improving Productivity and Market 
International Journal of Agriculture

ISSN 2520-4629X (Online)

Vol.6, Issue 1, No.1. pp 1 - 19, 2021

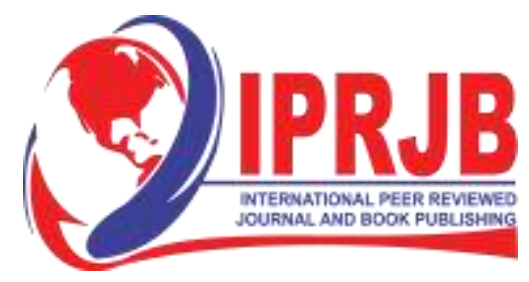

www.iprjb.org

Success (IPMS) of Ethiopian Farmers Project, ILRI (International Livestock Research Institute), Nairobi, Kenya.

Mubila, M. (2012). African Development Bank Group, Briefing Notes for AfDB's Long-Term Strategy (pp. 1-10) [Briefing Note 6: Inclusive Growth Agenda]. Retrieved from African Development Bank Group website: https://www.afdb.org/fileadmin/uploads/afdb/Documents/PolicyDocuments/FINAL\%20Briefing\%20Note\%206\%20Inclusive\%20Growth.pdf

Muriithi, B. W., \& Matz, J. A. (2015). Welfare effects of vegetable commercialization: Evidence from smallholder producers in Kenya. Food Policy, 50, 80-91

Mwanthi, M., \& Kimani, V. N. (1993). Agrochemicals: A potential health hazard among Kenyas small-scale farmers [Technical Report]. Retrieved from University of Nairobi Institutional Repository: http://41.204.161.209/handle/11295/61188

Nguetti, J. H., Imungi, J. K., Okoth, M. W., Wang'ombe, J., Mbacham, W. F., \& Mitema, S. E. (2018). Assessment of the knowledge and use of pesticides by the tomato farmers in Mwea Region, Kenya. African Journal of Agricultural Research, 13(8), 379-388.

Nicklett, E. J., Semba, R. D., Xue, Q.-L., Tian, J., Sun, K., Cappola, A. R., ... Fried, L. P. (2012). Fruit and vegetable intake, physical activity, and mortality in older communitydwelling women. Journal of the American Geriatrics Society, 60(5), 862-868.

Okado, M. (2001). Background Paper on Kenya off-season and specialty fresh fruits and vegetables: Lessons of experience from the Kenya horticultural industry. United Nations Conference on Trade and Development Regional Workshop for Horticultural Economies in Africa. Nairobi, Kenya.

Okello, J. J., \& Swinton, S. M. (2010). From Circle of Poison to Circle of Virtue: Pesticides, Export Standards and Kenya's Green Bean Farmers. Journal of Agricultural Economics, 61(2), 209-224. https://doi.org/10.1111/j.1477-9552.2009.00211.X

Okoffo, E., Mensah, M., \& Fosu-Mensah, B. (2016). Pesticide exposure and the use of personal protective equipment by cocoa farmers in Ghana. Environmental Systems Research, 5. https://doi.org/10.1186/s40068-016-0068-z

Oyebode, O., Gordon-Dseagu, V., Walker, A., \& Mindell, J. S. (2014). Fruit and vegetable consumption and all-cause, cancer and CVD mortality: Analysis of Health Survey for England data. J Epidemiol Community Health, 68(9), 856-862.

Oyugi, R. B. (2013). Pesticide residues in some vegetables rotated with tobacco using hplc, and farmers' awareness of pesticide health effects in Kuria-Migori, Kenya (Thesis, Kenyatta University). Retrieved from https://ir-library.ku.ac.ke/handle/123456789/6546

Pender, J. \& Alemu, D. (2007). Determinants of Smallholder Commercialization of Food Crops: Theory and Evidence from Ethiopia. IFPRI Discussion Paper 00745.International Food Policy Research Institute (IFPRI), Washington DC, USA. 
International Journal of Agriculture

ISSN 2520-4629X (Online)

Vol.6, Issue 1, No.1. pp 1 - 19, 2021

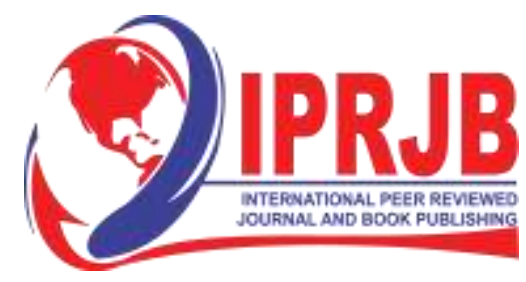

www.iprjb.org

Prabhakar, S., Sano, D and Srivastava, N. (2010). Food Safety in the Asia-Pacific Region: Current Status, Policy Perspectives and a Way Forward. In Sustainable Consumption and Production in the Asia-Pacific Region: Effective Responses in a Resource Constrained World, Institute for Global Environmental Strategies, White Paper III, pp 215-238. Institute for Global Environmental Strategies, Hayama, Japan.

Sambu, Z. (2013). Chemical ban hits vegetable exports to the EU market. Business Daily. Retrieved from https://www.businessdailyafrica.com/news/Dimethoatel-ban-hitsvegetable-exports-to-the-EU-market--/539546-1694416-owtu6hz/index.html

Schneider, M., Norman, R., Steyn, N and Bradshaw, D. (2007). Estimating the burden of disease attributable to low fruit and vegetable intake in South Africa in 2000. South Africa Medical Journal, 97(8):717-23.

Seale Jr, J. L., Regmi, A., \& Bernstein, J. (2003). International evidence on food consumption patterns (No. Technical Bulletin Number 1904; pp. 1-70). Retrieved from Electronic Report from the Economic Research Service website: https://www.ers.usda.gov/webdocs/publications/47429/14755_tb1904_1_.pdf?v=0

Sharma, P. V., \& Wardhan, H. (2015). Assessment of Marketed and Marketable Surplus of Major Foodgrains in India. Centre for Management in Agriculture (CMA) Indian Institute of Management.

Sharma R, K., Patel D, R., Chaudhari D, R., Kumar V., and Patel M, M. (2018) Effect of some fungicides against early blight of tomato (Lycopersicon esculentum Mill.) caused by Alternaria solani (Ell. \& Mart.) Jones and Grout and their impact on yield. International Journal of Current Microbiology and Applied Sciences 7(07): 1395 - 1401.

The Royal Society. (2009). Reaping the benefits Science and the sustainable intensification of global agriculture. London United Kingdom. Retrieved from https://royalsociety.org/ /media/Royal_Society_Content/policy/publications/2009/42949 67719.pdf

Thorbecke, E. (1970). The Role of Agriculture in Economic Development. UMI Publishers, Michigan, USA.

Thrupp, L. A. (1995). Bittersweet harvests for global supermarkets: Challenges in Latin America's agricultural export boom. World Resources Institute.

Tilman, D., Balzer, C., Hill, J., \& Befort, B. L. (2011). Global food demand and the sustainable intensification of agriculture. Proceedings of the National Academy of Sciences, 108(50), 20260-20264.

Timmer, C. P. (1997). Farmers and markets: The political economy of new paradigms. American Journal of Agricultural Economics 79(2):621-627.

Trichopoulou, A., Costacou, T., Bamia, C., \& Trichopoulos, D. (2003). Adherence to a Mediterranean diet and survival in a Greek population. The New England Journal of Medicine, 348(26), 2599-2608. https://doi.org/10.1056/NEJMoa025039 
Unnevehr, L. J. (2000). Food safety issues and fresh food product exports from LDCs. Agricultural Economics, 23(3), 231-240.

Von Braun, J., \& Kennedy, E. T. (1994). Agricultural commercialization, economic development, and nutrition. Published for the International Food Policy Research Institute. Retrieved from http://agris.fao.org/agrissearch/search.do?recordID=US201300304938

Waltner-Toews, D., \& Lang, T. (2000). A new conceptual base for food and agricultural policy: The emerging model of links between agriculture, food, health, environment and society. Global Change and Human Health, 1(2), 116-130.

WHO. (2014). Food safety. Fact sheet N0. 399 [Informational]. Retrieved from World Health Organiztion Fact sheets website: https://www.who.int/news-room/fact-sheets/detail/foodsafety

Woolverton, A., \& Neven, D. (Eds.). (2014). Understanding Smallholder Farmer Attitudes to Commercialization: The case of maize in Kenya. Retrieved from http://www.fao.org/3/ai3717e.pdf

World Bank. (2016). Kenya Country Economic Memorandum from Economic Growth to Jobs and Shared Prosperity (No. 103822; p. 164). Retrieved from World Bank website: http://documents.worldbank.org/curated/en/763771468197384854/pdf/103822-WPKenya-Country-Economic-Memorandum-PUBLIC.pdf 